\title{
Pre-Extension Demonstration of Improved Bread Wheat Varieties with Their Production Packages in High land Area of Eastern Amhara Region, Ethiopia
}

\author{
Abere Haile», Nigussie Siyum, Mekonnen Assefa, Mesfin Bahta \\ Amhara Regional Agricultural Research Institute, Sirinka Agricultural Research Center, P.O. Box 74, \\ Woldia, Ethiopia \\ ^Corresponding author email: Aberehaile15@gmail.com
}

\begin{abstract}
The study was basically focused on demonstration of bread wheat technologies for wider demand-driven technology diffusion in major wheat growing area in high land of eastern Amhara. The objectives were in order to evaluate and demonstrate improved bread wheat variety with their production package to the farming community and assess farmers and extension workers reaction towards improved bread wheat technology. The activity was conducted in main season 2019/2020 at Jama and Meket districts. The fact that wheat production and productivity in the region as well as in the particular study area low because farmers are using low yielding, disease and pest resistant local varieties. The improved bread wheat variety was demonstrated along with the local variety at 12 farmers' fields. Yield data, economic data, farmers' perception and preferences were collected throughout the demonstration stages and data were analyzed by using ANOVA, partial budget analysis and preference ranking. The results of ANOVA showed that yield and yield related parameters statistically significant at the probability level of $0.01 \%$ and $0.05 \%$ among treatments. The highest mean yield was recorded from "Hibist" with improved management 2.49 ton/ha and 1.42 ton/ha at Jama and Meket districts respectively followed by local with improved management and the lowest was from local with farmers practices. Furthermore, the result of partial budget analysis show that the use of improved and local variety with recommended package more profitable with the MRR of 1.96 and 0.81 than farmer practices at Jama district and 74.26 and 9.26 at Meket district respectively. Farmer preference analysis improved \& local variety with improved management ranks $1^{\text {st }}$ and $2^{\text {nd }}$ at Jama respectively while reverse at Meket and lastly ranks farmer practices at both districts. Generally, improved bread wheat with recommended package has higher yield advantage, financial feasibility and social acceptance than control and farmer practices, it is recommended to be scale out for further dissemination.
\end{abstract}

Keywords: bread wheat; demonstration; improved management; farmers and field day

\section{INTRODUCTION}

Wheat (Triticum aestivum $\mathrm{L}$ ) belongs to the grass family Poaceae and to the tribe Hordea in which several flowered spikelets are sessile and alternate opposite side of the rachis forming a true spike. It is a major crop contributing importantly to the nutrient supply of the global population and also a very versatile crop; it shows wide adaptation to diverse agro-ecological conditions and cropping. Ethiopia is the second largest producer of wheat in Sub-Saharan Africa next to South Africa. Recently, wheat in general has become one of the most important cereal crops in terms of production and food security in Ethiopia (Tolesa, 2014).

The crop has been cultivated in the country since the time of immemorial and is the second largest wheat producer in sub-Saharan
Africa, after South Africa. It is third in area of cultivation following tef and maize and cultivated in Ethiopia on about 1.69 million hectares and delivering about 4.56 million tons of grain yields (CSA, 2016/17). The country is also the major producer of wheat in eastern Africa accounting for over $70 \%$ of the total wheat area in the region (Bezabeh et al., 2015). Although most of the wheat grown in Ethiopia is bread wheat, both bread and durum wheat are widely grown in the country constituting about $60 \%$ and $40 \%$ of the total wheat production, respectively (CIMMYT, 2014)

Wheat is one of the most important small cereal crops in Ethiopia widely cultivated in wide range of altitudes. Most wheat producing area in Ethiopia lie between $6^{\mathrm{O}}$ and $16^{\mathrm{O}} \mathrm{N}$ latitude and $35^{\mathrm{O}}$ and $42^{\mathrm{O}} \mathrm{E}$ 
longitudes of an altitude range from 1500 to 3000 meters above sea level (m.a.s.l). But the most suitable agro-ecological zones fall between 1900 to 2700 meters above sea level (Bekele et al., 2000). Wheat in Ethiopia is produced exclusively under rain fed conditions with rain fall amount ranging from $600 \mathrm{~mm}$ to $2000 \mathrm{~mm}$. Currently, Oromia, Amhara, Southern Nations Nationalities and peoples region (SNNPR) and Tigray regions are the major wheat producing areas in Ethiopia (Warner et.al, 2015). It is grown annually on 1.66 million hectare of land in Ethiopia with a total production of 4.23 million tons with an average productivity of 2.54 t ha-1 which makes the country the second largest wheat producers in subSaharan Africa (CSA, 2015). While Amhara National Regional State is among the most important wheat growing areas of the country which accounts for 529609.63 hectare of the area coverage and 1195823.247 tons of the total production with an average productivity of $2.3 \mathrm{t}$ ha-1 (CSA, 2015).

Wheat is used for the manufacture of flour for different purposes such as bread, biscuits and pasta products such as macaroni, spaghetti and noodle are some of the industrial products. Traditionally wheat used for making the traditional staple food like "Injera" bread ("dabo"), "dabokolo", local beer ("tella"), local spirit ("areki"), "kollo", "'genfo", "kinche", "nifro" and other types of food in the Ethiopian context. In addition, its straw is frequently used in house construction, especially as roof thatching material and as feed for livestock. It can provide more protein than any other cereal crops (Hussein et al., 2006). Wheat contributes approximately 200 calories per day in urban areas compared to about 310 calories in rural areas. It accounts for about $12 \%$ of the national calorie intake (Omer Gebremedhin, 2015). Furthermore, wheat has been selected as one of the target crops in the strategic goal of attaining national food self-sufficiency, income generation, poverty alleviation and achieving socioeconomic growth of the country (Mulatu, 2015).

Although the country is the major producer in sub Saharan Africa, it is still reliant on foreign wheat import to satisfy its demands. Wheat productivity is for below the crop's potential mainly due to biotic and a biotic constraint. Cultivation of local low yielding varieties, inadequate and erratic rainfall, poor agronomic practices, diseases and insect pests are among the principal limitations to wheat production in Ethiopia (Gorfu and Hiskias, 2000).

Moreover, wheat has tremendous opportunities for its production like; high policy support, higher Market price, and increased consumption by farm households and a number of improved Bread wheat high yielding varieties (HYVs) have been released by both national and regional research centers. However, its production in the region as well as in the particular study area do not exceed $1.2 \mathrm{t} / \mathrm{ha}$. This is because the farmers are using low yielding and disease and pest resistant local varieties, traditional practices and other different natural disasters. Besides, previously introduced improved varieties have been withdrawn from production due to incidence of pest and diseases. The newly released wheat variety Hibist (ETBW7690) by Sirinka agricultural research center in 2016 which is high yielder, disease resistant and adaptable in the study area. Hence, promotion of newly released wheat varieties with their production package is important in order to bring impact and enable to enhance farmers income. Therefore, this study was initiated with the following specific objectives a) to evaluate and demonstrate improved bread wheat variety with their production package to the farming community; and b) to assess farmers and extension workers reaction towards improved bread wheat technology. 


\section{METHODS}

\section{Description of the study area}

The study was conducted at Meket and Jama districts in the high land of North and South Wollo for 2019/2020 main cropping season. The experimental farmers' field are diverse in soil type, annual rainfall and positional information. Generally, rainfall starts at June and extends to ends of November and maximum rainfall was received from July to August. The districts are well known in the production of wheat, barley and high land pulse crops. The general description of study area specifically, Meket district is geographically located at $11^{\circ} 45^{\prime} 02^{\prime \prime} \mathrm{N}$ and $34^{\circ} 44^{\prime} 57^{\prime \prime} \mathrm{E}$ latitude and longitude, respectively. The district has an altitude of 2872 m.a.s.l. Its annual average rainfall and temperature are $931 \mathrm{~mm}$ and $16^{\circ} \mathrm{C}$, respectively. Jama district also located at $10^{\circ} 27^{\prime} 18^{\prime \prime} \mathrm{N}$ and $39^{\circ} 16^{\prime} 01^{\prime \prime} \mathrm{E}$ latitude and longitude, respectively. The district has an altitude of 2622 m.a.s.l. Its annual average rainfall and temperature are $725 \mathrm{~mm}$ and $16^{\circ} \mathrm{C}$, respectively.

\section{Experimental design and procedure}

The target district and kebeles were selected purposively based on bread wheat production potential and representativeness for the study. Host farmers were also selected purposively based on their willingness to conduct the trial and accessibility of their respective farms for close follow up and monitoring. Package training were given for host farmers, experts and development agents regarding the specific task of field experimental operation. varieties were evaluated using the participatory method. The experiment was done on 12 farmers' fields; farmers as a replication using the treatment materials of improved bread wheat variety with improved management, local variety with improved management and local variety with farmers (local) practices with the experimental plot size $10 \mathrm{~m}^{*} 10 \mathrm{~m}\left(100 \mathrm{~m}^{2}\right)$ per each treatment.
Agronomic practices were employed based on recommendation. Evidence suggests there would be substantial increases in crop yields on Vertisols if excess surface soil water were drained off and if appropriate cropping practices were used (Amare, 2015). For instance seed rate $125 \mathrm{~kg} / \mathrm{ha}$ with $20 \mathrm{~cm}$ row drilling and $150 \mathrm{~kg} / \mathrm{ha}$ for broadcast system in both districts; but fertilizer application different because Meket is litosol while Jama is vertisol so, fertilizer recommendation for Meket $100 \mathrm{~kg} / \mathrm{ha}$ dup $(121 \mathrm{~kg} / \mathrm{ha}$ NPS) and $100 \mathrm{~kg} / \mathrm{ha}$ urea while for Jama $225 \mathrm{~kg} / \mathrm{ha}$ dup $(272 \mathrm{~kg} / \mathrm{ha}$ NPS) and $275 \mathrm{~kg} / \mathrm{ha}$ urea with considering split application. Vertisol recommendation of "Broad Bed Furrow" (BBF) $80 \mathrm{~cm} * 40 \mathrm{~cm}$ used for exact drainage of water; Jama district experimental layout $10 \mathrm{~cm} * 10 \mathrm{~cm}$ with $80 \mathrm{~cm} * 40 \mathrm{~cm}$ broad bed furrow $(\mathrm{BBF})$ for improved practices and $40 \mathrm{~m} * 20 \mathrm{~cm}$ BBF of farmers' practices. A surface drainage technology known as "Broad Bed and Furrow" (BBF), constructed by Broad Bed Maker (BBM), has been developed and popularized after on- station and on- farm testing in various areas in the highlands (Teklu et al., 2001).

\section{Approaches and methods used}

Farmers Research Extension Group /FREG/

The approaches followed during the implementation of varieties were establishing farmers research and extension group (FREG) and multidisciplinary team of farmers, researchers and extension workers. Those small groups of farmers and extension workers groups are instrument that play pivotal role for evaluating of bread wheat varieties at each stage. The FREG approach refers to the research method through which a team of researchers, extension workers and group of farmers work together jointly conduct research on selected topics based on farmers' need and interest on farmers' fields in the process of technology generation, verification, demonstration and improvement (Chimdo, 
2008; JICA, 2015). Bread wheat varieties were planted on farmers' field and almost all farmers group members, researchers, extension workers presented and evaluated the varieties at vegetative and maturity stage.

Training. Full package training were delivered for 25 host farmers among (6 female), 2 woreda agricultural experts and 11 development agents from this 3 were female extension workers.

Field day. Field days and field visit were organized two times once during vegetative and maturity stage of the plant. During field day, key actors (farmers, agricultural experts, and researcher) and other stakeholders were participated for technology evaluation.

\section{Method of data collection}

The data were collected by focus group discussion, field observation and formal data sheet used. Type of data both primary and secondary means biological, social and economical data were collected. Biological data such as grain and straw yield in ton/ha and yield related parameters like plant height, spike length, economical data market price of output (grain and straw), costs of inputs (fertilizer, labor, seed and chemical cost) and social data also attitudes and perception of farmers and other stakeholders opinion.

\section{Method of data analysis}

The collected data analyzed by analysis of variance (ANOVA) were performed using Gen Stat software for yield and yield related traits. Duncan's Multiple Range Test (DMRT) was used to compare means among varieties (Steel and Torrie, 1980). According to CIMMYT (1988), partial budget and sensitivity analysis were used to determine the level of profitability of improved technologies over the conventional practice indicated table $2 \&$ 3.below. The partial budget analysis method adopted for this study is defined as:

$$
\begin{aligned}
& \mathrm{NB}=\mathrm{GB}-\mathrm{TC} \\
& \mathrm{MB}=\mathrm{NBIV}-\mathrm{NBLC} \\
& \mathrm{MC}=\mathrm{TCIV}-\mathrm{TCLC} \\
& \mathrm{MNB}=\mathrm{MR}-\mathrm{MC} \\
& \mathrm{MRR}=\mathrm{MB} / \mathrm{MC} * 100 \%
\end{aligned}
$$

Where, $\mathrm{NB}=$ Net benefit; $\mathrm{GB}=$ Gross benefit; $\mathrm{TC}=$ Total cost $\mathrm{MB}=$ Marginal benefit $\mathrm{MC}=$ Marginal cost; $\mathrm{MNB}=$ Marginal net benefit; NBIV= net benefit of improved variety; $\mathrm{TCIV}=$ total cost of improved variety; TCLC $=$ total cost of local cultivar; $\mathrm{TR}=$ Total revenue; $\mathrm{MR}=$ Marginal revenue; $\mathrm{TVC}=$ Total variable cost; $M R R=$ Marginal rate of return.

On the other hand, Pair wise ranking was used to analyze perception of farmers towards bread wheat varieties. Ranking was used to identify the best varieties preferred by farmers using the following procedure. Thus, selection criteria were identified first, then ranking was given for each criterion and finally acceptability rank was determined. Lastly, Spearman's rank correlation coefficient was determined to see degree of coincidence between farmers' preference rank with the actual value of measured attributes (Ferdous et al. 2016). Hence, Spearman's rank correlation coefficient calculated as follow;

Spearman's rank correlation coefficient expressed in percentage $\quad r_{s}=1-\frac{6 \sum d^{2}}{n\left(n^{2}-1\right)}$ where, $d=$ difference in the ranks assigned to the same individual or phenomenon (actual yield ranks minus farmers preference rank in this case) and $n=$ number of individuals or phenomena ranked (number of varieties in this case). 


\section{RESULTS AND DISCUSSIONS}

\section{Yield and yield related parameters performance of bread wheat varieties}

As shown in Table 1 below, the improved variety ("Hibist") with improved management, local variety with improved management and local variety with farmer practices gave mean grain yield of 2.49 ton/ha, 1.91 ton/ha and 1.17 ton/ha at Jama district while 1.42 ton/ha, 1.08 ton/ha and $0.77 \mathrm{ton} / \mathrm{h}$ at Meket district respectively. The yield data indicates that improved variety with improved management has high grain yield than local varieties in both locations.
The ANOVA result in Table 1, shows that the demonstrated bread wheat varieties statistically significant difference between treatments with grain yield and biomass yield across locations at $(\mathrm{p}<1 \%)$. Likewise plant height at Jama and spike length at Meket were also significant at $(\mathrm{p}<5 \%)$ and plant height at Meket and spike length at Jama were significant at $(\mathrm{p}<1 \%)$. Moreover, Duncan's Multiple Range Test (DMRT) was used to compare means among varieties. Hibist bread wheat variety with recommended package was best performing technologies based on yield and yield related parameters

.Table 1. ANOVA tables for different agronomic traits

\begin{tabular}{lcccc|cccc}
\hline \multirow{2}{*}{ Varieties } & \multicolumn{4}{c|}{ Meket } & \multicolumn{4}{c}{ Jama } \\
\cline { 2 - 9 } & $\begin{array}{l}\mathrm{PH} \\
\mathrm{Cm}\end{array}$ & $\begin{array}{c}\mathrm{SL} \\
\mathrm{Cm}\end{array}$ & $\begin{array}{c}\mathrm{BY} \\
\mathrm{t} / \mathrm{ha}\end{array}$ & $\begin{array}{c}\mathrm{GY} \\
\mathrm{t} / \mathrm{ha}\end{array}$ & $\begin{array}{c}\mathrm{PH} \\
\mathrm{Cm}\end{array}$ & $\begin{array}{c}\mathrm{SL} \\
\mathrm{Cm}\end{array}$ & $\begin{array}{c}\mathrm{BY} \\
\text { t/ha }\end{array}$ & $\begin{array}{c}\mathrm{GY} \\
\text { t/ha }\end{array}$ \\
\hline $\begin{array}{l}\text { Improved variety X } \\
\text { improved Management }\end{array}$ & $83.6 \mathrm{~b}$ & $5.83 \mathrm{a}$ & $4.05 \mathrm{a}$ & $1.42 \mathrm{a}$ & $87.7 \mathrm{a}$ & $7.67 \mathrm{a}$ & $7.61 \mathrm{a}$ & $2.49 \mathrm{a}$ \\
$\begin{array}{l}\text { Local variety X } \\
\text { improved management }\end{array}$ & $99.8 \mathrm{a}$ & $5.47 \mathrm{ab}$ & $4.42 \mathrm{a}$ & $1.08 \mathrm{~b}$ & $92.2 \mathrm{ab}$ & $6.73 \mathrm{~b}$ & $6.94 \mathrm{a}$ & $1.91 \mathrm{~b}$ \\
$\begin{array}{l}\text { Local variety X local } \\
\text { management }\end{array}$ & $95.4 \mathrm{a}$ & $4.83 \mathrm{~b}$ & $3.04 \mathrm{~b}$ & $0.77 \mathrm{~b}$ & $82.5 \mathrm{~b}$ & $5.83 \mathrm{c}$ & $5.17 \mathrm{~b}$ & $1.17 \mathrm{c}$ \\
Grand mean & & & & & & & & \\
CV (\%) & 92.9 & 5.38 & 3.84 & 1.09 & 87.5 & 6.74 & 6.57 & 1.85 \\
Sig & 12.2 & 22.9 & 29.7 & 27.6 & 3.0 & 5.9 & 20.4 & 20.1 \\
\hline
\end{tabular}

Source: Own field result 2019/2020

N.B PH=Plant height, SL=Spike Length, BY=Biomass yield and GY=Grain Yield (the sign **,***Mean difference is significant at $0.05 \%$ and $0.01 \%$ )

\section{Partial budget analysis}

In the demonstration experiment partial budget analysis show the economic effect of changing from one treatment to another. Based on input and output price illustrated in Table 2 below the gross net benefit was calculated for the three treatments. Improved and local bread wheat variety with improved management and local variety with farmer practices has a net benefit of 15,173.06 $\mathrm{ETB} / \mathrm{ha}, 9342.56 \mathrm{ETB} / \mathrm{ha}$ and $4283 \mathrm{ETB} / \mathrm{ha}$ at Meket district while 15,714.1 ETB/ha, 8,050.8
ETB/ha and 2,629.6 ETB/ha at Jama district respectively.

The mean grain and straw yield were adjusted by $10 \%$ for capturing of yield penalty for partial budget analysis. The result of partial budget analysis in Table 2 indicated that improved and local variety with improved management had shown a marginal rate of return $196 \% \& 81 \%$ over the local variety with farmer practices respectively. This implies that for 1 birr additional cost on the growing of improved and local variety with recommended package can be gained an 
additional benefit of 1.96 ETB \& 0.81 ETB after covering the input cost respectively at Jama district.

On the other hand, improved and local variety with improved management had shown a marginal rate of return $7426 \%$ \& 926\% over the local variety with farmer practices respectively. This implies that for 1.00 ETB additional cost on the growing of improved and local variety with recommended package can be gained an additional benefit of 74.26 ETB \& 9.26 ETB after covering the input cost respectively at Meket district.

Generally, the use of improved variety Hibist with improved production package provided a higher net benefit followed by the local variety with improved management lastly local variety with farmers' practice (Table 2) below. Since marginal rate of return (MRR) is > $100 \%$ adopting the improved bread wheat variety with improved production package is economically feasible (CIMMT, 1998) manual.

\section{Sensitivity analysis}

The sensitivity analysis is a change in the net benefit and the return on marginal capital as revenue and input prices vary by $15 \%$ above and below their values. As shown in Table 10, the calculated sensitivity analysis at $15 \%$ input cost increment and output decrement revealed that the marginal rate of return for growing improved and local bread wheat variety with its full package is higher than the generally accepted minimum rate of return i.e. $100 \%$. Even the price shock exist both input cost increment and price of output decreasing the use of improved and local varieties with recommended package more profitable than the local variety with farmer practices in both locations.

\section{Farmers' preference analysis}

Farmers' participation in the variety selection process has a paramount role to identify farmers' preferred traits in promoting best bread wheat varieties. Discussion was held with farmers to help them in identifying selection criterion like spike length, number of tiller, earliness, frost resistance, rust resistance and productivity are the identified selection criteria for best bread wheat varieties. The next step was to rank the criteria so as to easily prioritize each criterion for the selection process as (Table 3 and Table 6). For instance, frost resistance $=$ productivity, rust resistance $=$ earliness and spike length were the top three priorities of bread wheat variety selection criteria by the farmers at Jama district (Table 3) and five preference parameters High yielder, Rust resistance, Earliness, frost resistance and plant height in descending order) were identified and weighted on the bases of their significance in Meket district (Table 6).

Following the procedures, sum score given to each variety based on each criterion rank (Table 4 and Table 7). Finally, the comparison result of the weighted ranking matrix thus revealed that a best technology which has lower aggregated product was peaked as a primary choice. This means that farmers were invited to select the promising varieties Hibist and local with improved production package have been selected as the promising varieties by scoring 13 and 26 values, respectively, but the highest scored 39 by Local variety is last ranked in Jama district (Table 5). In addition, Hibist, local variety and local variety with farmer practice have been selected as the promising varieties by scoring 27,24 and 35 values respectively at 
Meket district (Table 8). In line to this finding (Wondimu, 2016) and (Tafere et al., 2012) stated that the lower value score the $1^{\text {st }}$ ranked variety by farmers selection.

Generally, the result of farmers' preference analysis showed that farmers were ranking the accredited preference criteria pair-wisely and then considered the rank as weight. The scores given by farmers to each variety were multiplied by the respective weight. Products were aggregated for each variety for final selection $(1,2,3 ; 1=$ the best) (Russell,1997). Were the improved variety with improved management, local variety with improved management and local with farmer's practices ranks $1^{\text {st }}, 2^{\text {nd }}$ and $3^{\text {rd }}$ at Jama district (Table 5) likewise, $2^{\text {nd }}, 1^{\text {st }}$ and $3^{\text {rd }}$ at Meket district (Table 8) respectively due to the weighted parameters of selection criteria. In line with this finding stated that improved variety with full package was selected as top ranking or adapted variety by farmers' selection (Teame et al., 2017).

\section{Farmers preference versus Actual yield comparison (Correlation)}

The result of spearman's correlation coefficient ( $\mathrm{r}=1$ and $\mathrm{r}=0.75$ at Jama and Meket respectively). Therefore, spearman's correlation coefficient results show Table 9 below indicates that farmers' evaluation rank and the actual measurement rank coincides at $75 \%$ and $100 \%$ at Meket and Jama districts respectively.

\section{Feedback provided by farmers}

Most farmers feedback were improved variety "Hibist" with improved management has many advantage as we compared to local variety. Which has long spike length, highly productive, marketable seed size and color means that preferable for bread powder industry and household consumption. But its straw not palatable for animal. Whereas local variety found at Jama locally called "Qurisht" can resistance for water logging problem, cannot shatter at maturity time, its straw highly palatable for animals feed and wheat is staple food crop which has multi-purpose use for household consumption. This in line with (Aleligne and Regassa, 1992) wheat is used to prepare a range of products; the traditional staple food ("Injera"), bread ("dabo"), local beer ("tella"), local spirit ("areki"), and several other local food items ("kollo", "'genfo" and "nifro").

But the major problem of local variety that was dislike with most farmers' cannot resistance to disease like yellow rust, Septoria leaf blotch and they were also late maturing so, as they cannot escape frost occurrence season, they have also thresh-ability problem and its spike length too short as we compared to the improved variety. Moreover, farmer practices especially in vertisoil practices broad bed furrow (BBF) not more than $40 \mathrm{~cm} * 20 \mathrm{~cm}$ this become eroded with high run off flooding and excessive water cannot be drained. In general local variety with farmers practice not productive and feasible. 
Table 2. Result of partial budget analysis

\begin{tabular}{|c|c|c|c|c|c|c|}
\hline \multirow[b]{2}{*}{ Particulars } & \multicolumn{3}{|c|}{ Meket } & \multicolumn{3}{|c|}{ Jama } \\
\hline & 1 & 2 & 3 & 1 & 2 & 3 \\
\hline Adjusted grain yield (ton/ha) & 1.28 & 0.97 & 0.69 & 2.24 & 1.72 & 1.05 \\
\hline Adjusted straw yield (ton/ha) & 3.65 & 3.98 & 2.74 & 6.85 & 6.25 & 4.65 \\
\hline Farm gate price of grain (birr/Kg) & 18.40 & 20.80 & 20.80 & 16.50 & 16.50 & 16.50 \\
\hline Farm gate price of straw (birr/ton) & 300.00 & 300.00 & 300.00 & 500.00 & 700.00 & 700.00 \\
\hline Income from sale of grain (birr/ha) & 23515.20 & 17884.80 & 12751.20 & 36976.50 & 28363.50 & 17374.50 \\
\hline Income from sale of straw (birr/ha) & 1093.50 & 1193.40 & 820.80 & 3424.50 & 4372.20 & 3253.10 \\
\hline Total revenue (birr/ha) & 24608.70 & 19078.20 & 13572.00 & 40401.00 & 32735.70 & 20627.60 \\
\hline Marginal revenue (ETB/ha) & 11036.70 & 5506.20 & - & 19773.40 & 12108.10 & - \\
\hline Seed cost (birr/kg/ha) & 2300.00 & 2600.00 & 3120.00 & 1875.00 & 1875.00 & 2250.00 \\
\hline Fertilizer cost (birr/kg/ha) & 3055.64 & 3055.64 & 2744.00 & 6089.90 & 6089.90 & 4228.00 \\
\hline Labor cost (birr/man/day/ha) & 4080.00 & 4080.00 & 3425.00 & 16720.00 & 16720.00 & 11520.00 \\
\hline Total costs that vary (birr/ha) & 9435.64 & 9735.64 & 9289.00 & 24684.90 & 24684.90 & 17998.00 \\
\hline Marginal cost (ETB/ha) & 146.64 & 546.64 & - & 6686.90 & 6686.90 & - \\
\hline Net benefit (birr/ha) & 15173.06 & 9342.56 & 4283.00 & 15714.10 & 8050.80 & 2629.60 \\
\hline Marginal net benefit (birr/ha) & 10890.06 & 5059.56 & - & 13084.50 & 5421.20 & - \\
\hline MRR & 74.26 & 9.26 & - & 1.96 & 0.81 & - \\
\hline $\operatorname{MRR}(\%)$ & 7426.00 & 925.50 & - & 196.00 & 81.00 & - \\
\hline
\end{tabular}


Table 3. Pair wise ranking matrix of attributes or criteria ranking for bread wheat at Jama

\begin{tabular}{lcccccccc}
\hline Parameters & Spike length & Tiller Number & Earliness & Frost Resistance & Rust Resistance & Productivity & Score & Rank \\
\hline Spike length & $\mathrm{X}$ & Spike length & Earliness & Frost Resistance & Rust Resistance & Productivity & 1 & $3^{\text {rd }}$ \\
Tiller Number & & $\mathrm{X}$ & Earliness & Frost Resistance & Rust Resistance & Productivity & 0 & $4^{\text {th }}$ \\
Earliness & & & $\mathrm{X}$ & Earliness & Rust Resistance & Productivity & 3 & $2^{\text {th }}$ \\
Frost resistance & & & & X & Frost Resistance & Frost Resistance & 4 & $\mathbf{1}^{\text {th }}$ \\
Rust resistance & & & & & X & Productivity & 3 & $2^{\text {th }}$ \\
Productivity & & & & & & X & 4 & $\mathbf{1}^{\text {th }}$
\end{tabular}

Table 4. Sum score given to each variety based on each criterion in Jama district ( $\mathrm{N}=21)$

\begin{tabular}{lcccccc}
\multicolumn{1}{c}{ Variety } & \multicolumn{2}{c}{ Criteria } & & \\
& $\mathrm{SL}$ & $\mathrm{NT}$ & $\mathrm{ER}$ & $\mathrm{FR}$ & $\mathrm{RR}$ & $\mathrm{P}$ \\
Improved variety with improved Management & $87(1)$ & $124(1)$ & $48(1)$ & $26(1)$ & $72(1)$ & $25(1)$ \\
Local variety with improved management & $117(2)$ & $140(2)$ & $134(2)$ & $72(2)$ & $134(2)$ & $54(2)$ \\
Local variety with local management & $201(3)$ & $264(3)$ & $146(3)$ & $81(3)$ & $150(3)$ & $72(3)$ \\
\hline
\end{tabular}

Table 5. Final acceptability rank of varieties at Jama district

\begin{tabular}{|c|c|c|c|c|c|c|c|c|}
\hline \multirow[b]{2}{*}{ Variety } & \multicolumn{6}{|c|}{ Criteria with their weights } & \multirow[b]{2}{*}{ Total } & \multirow[b]{2}{*}{ Rank } \\
\hline & $\begin{array}{l}\text { SL } \\
\text { (3) }\end{array}$ & $\begin{array}{l}\text { NT } \\
\text { (4) }\end{array}$ & $\begin{array}{l}\text { ER } \\
\text { (2) }\end{array}$ & $\begin{array}{l}\text { FR } \\
\text { (1) }\end{array}$ & $\begin{array}{l}\text { RR } \\
\text { (2) }\end{array}$ & $\begin{array}{c}\mathrm{P} \\
\text { (1) }\end{array}$ & & \\
\hline Improved variety with improved Management & 3 & 4 & 2 & 1 & 2 & 1 & 13 & $1^{\text {st }}$ \\
\hline Local variety with improved management & 6 & 8 & 4 & 2 & 4 & 2 & 26 & $2^{\text {nd }}$ \\
\hline Local variety with local management & 9 & 12 & 6 & 3 & 6 & 3 & 39 & $3^{\text {rd }}$ \\
\hline
\end{tabular}

N.B $S L=$ Spike length, $N T=$ Number of tiller, $E R=$ Earliness, $F R=$ Frost resistance, $R R=$ Rust resistance, $P=$ Productivity. 
Table 6. Pair wise ranking matrix of attributes for bread wheat at Meket district

\begin{tabular}{|c|c|c|c|c|c|c|c|}
\hline List of Criteria & Rust tolerance & Frost tolerance & Earliness & Plant height & Yield & Total Score & Rank \\
\hline Rust tolerance & & Rust tolerance & Rust tolerance & Rust tolerance & Yield & 3 & $2^{\text {nd }}$ \\
\hline Frost tolerance & & & Earliness & Frost tolerance & Yield & 1 & $4^{\text {th }}$ \\
\hline Earliness & & & & Earliness & Yield & 2 & $3^{\text {rd }}$ \\
\hline Plant height & & & & & Yield & 0 & $5^{\text {th }}$ \\
\hline High Yielder & & & & & & 4 & $1^{\mathrm{st}}$ \\
\hline
\end{tabular}

Table 7. Sum score given to each variety based on each criterion in Meket district ( $\mathrm{N}=6)$

\begin{tabular}{lccccc}
\hline & \multicolumn{5}{c}{ Criteria } \\
\cline { 2 - 5 } Variety & RT & FT & EA & PH & HY \\
\hline Improved variety with improved Management & $24(1)$ & $56(2)$ & $33(2)$ & $110(2)$ & 1 \\
Local variety with improved management & $50(3)$ & $56(2)$ & $24(1)$ & $45(1)$ & 2 \\
Local variety with local management & $38(2)$ & $52(1)$ & $51(3)$ & $125(3)$ & 3
\end{tabular}

N.B RT= Rust tolerance, $F T=$ Frost tolerance, EA= Earliness, $P H=$ Plant height and HY=High yielder.

Table 8. Product of weights given to the criteria and rank of the varieties used to determine final acceptability rank Meket district

\begin{tabular}{lccccccc}
\hline \multicolumn{1}{c}{ Variety } & \multicolumn{4}{c}{ Criteria with their weights } & \multicolumn{2}{c}{ Total } & Rank \\
& RT (2) & FT (4) & EA (3) & PH (5) & HY(1) & \\
\hline Improved variety with improved Management & 2 & 8 & 6 & 10 & 1 & 27 & $2^{\text {nd }}$ \\
Local variety with improved management & 6 & 8 & 3 & 5 & 2 & 24 & $1^{\text {st }}$ \\
Local variety with local management & 4 & 4 & 9 & 15 & 3 & 35 & $3^{\text {rd }}$ \\
\hline
\end{tabular}


Table 9. Spearman's correlation coefficient of Farmers' evaluation rank with actual yield Rank

\begin{tabular}{lcccc}
\hline & \multicolumn{2}{c}{ Meket } & \multicolumn{2}{c}{ Jama } \\
\cline { 2 - 5 } Varieties & Farmers Rank & Actual Rank & Farmers Rank & Actual Rank \\
\hline $\begin{array}{l}\text { Improved variety with } \\
\text { improved Management }\end{array}$ & 2 & 1 & 1 & 1 \\
$\begin{array}{l}\text { Local variety with improved } \\
\text { management }\end{array}$ & 1 & 2 & 2 & 2 \\
$\begin{array}{l}\text { Local variety with local } \\
\text { management }\end{array}$ & 3 & 3 & 3 & 3 \\
$\begin{array}{l}\text { Spearman's rank correlation } \\
\text { coefficient }(\text { Rs })\end{array}$ & 0.75 Means $75 \%$ & 1 Means $100 \%$ \\
\hline
\end{tabular}

Table 10 Sensitivity analysis if fertilizer cost increase $15 \%$ and price of yield decrease $15 \%$

\begin{tabular}{lccc|ccc}
\hline & \multicolumn{3}{c}{ Meket } & \multicolumn{3}{c}{ Jama } \\
\hline Particulars & 1 & 2 & 3 & 1 & 2 & 3 \\
\hline TVC & 9893.99 & 10193.99 & 9700.60 & 25598.39 & 25598.39 & 18632.20 \\
MC & 193.39 & 493.39 & - & 6966.19 & 6966.19 & - \\
NB & 11023.41 & 6022.48 & 1835.60 & 8742.47 & 8742.47 & -1098.74 \\
MNB & 9187.81 & 4186.88 & - & 9841.20 & 9841.20 & - \\
MRR & 47.51 & 8.49 & - & 1.40 & 1.40 & - \\
MRR \% & 4751.00 & 849.00 & - & 141.00 & 141.00 & - \\
\hline
\end{tabular}

Source: Own result 2019/2020

N.B Treatments were $1=$ Hibist with improved management, $2=$ Local variety with improved management and 3=Local variety with farmer practices, TR=Total revenue, MR=Marginal revenue, TVC= Total variable cost, $M C=$ Marginal cost, $N B=$ Net benefit, $M N B=$ Marginal net benefit, MRR=Marginal rate of return. 
Major events under taken during demonstration of bread wheat in both location

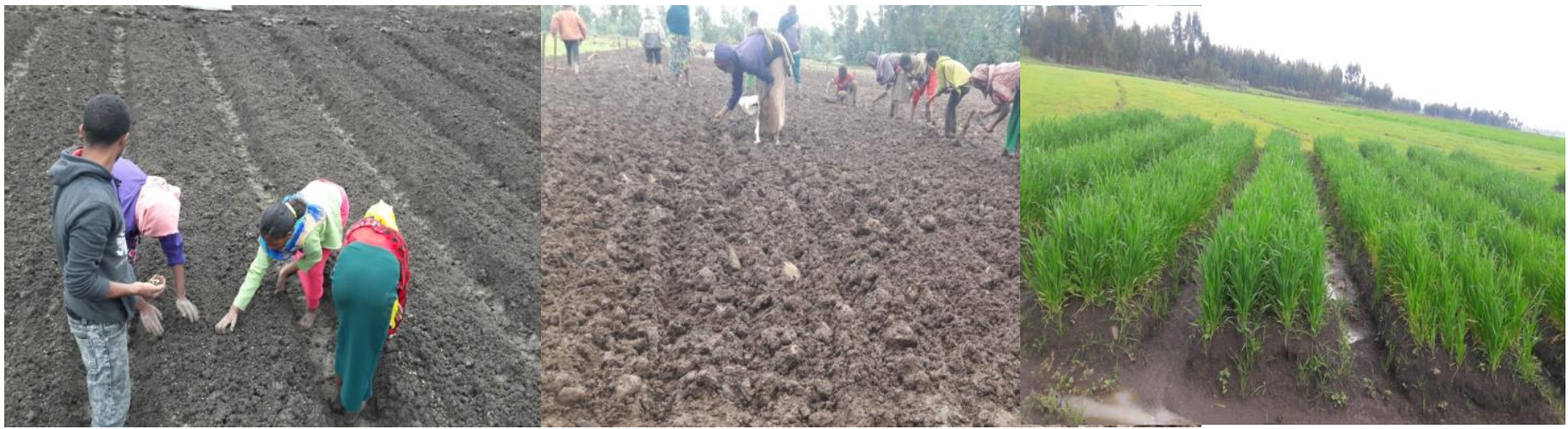

Fig-1. Planting time at Jama

Fig-2. Planting time at Meket

Fig-3 Vegetative performance at Jama

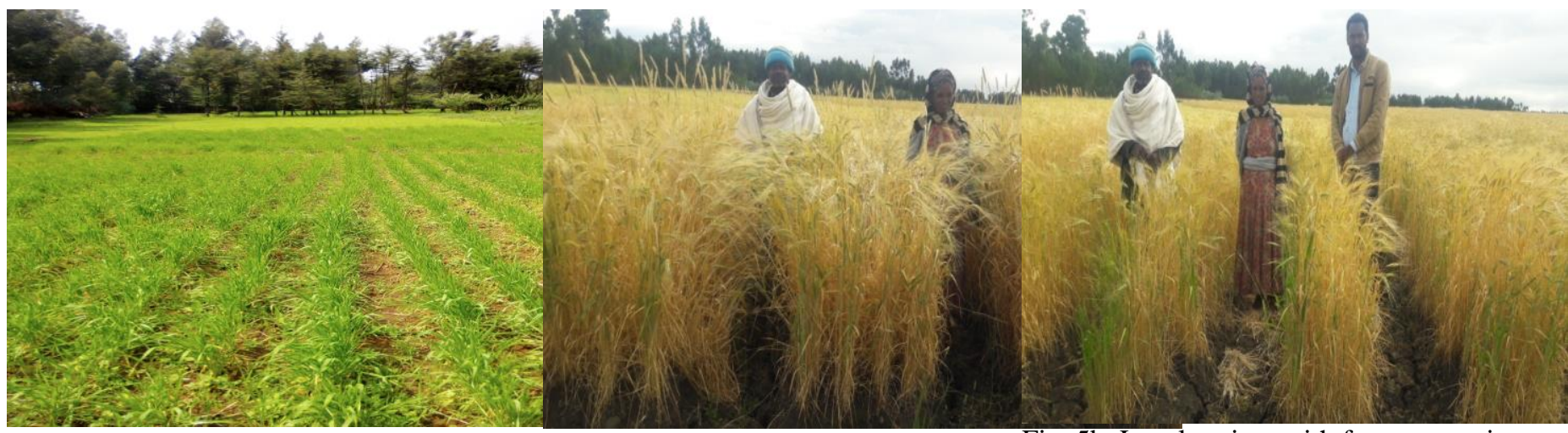

Fig-4 Vegetative performance at Meket

Fig 5a. Local variety with improved management
Fig. 5b. Local variety with farmer practices management

Fig-5. Bread wheat varieties


selection and evaluation by farmers and development agents at maturity stage

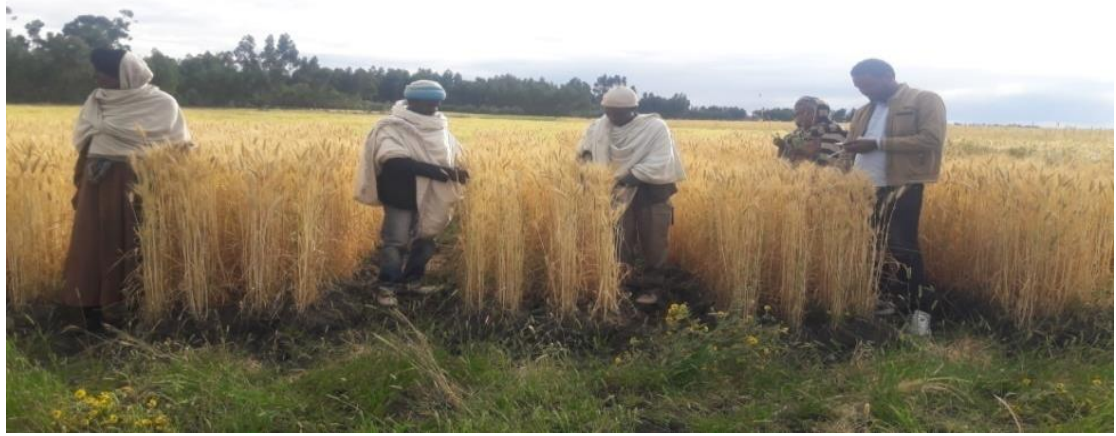

Fig 5c. Improved variety with improved management

\section{CONCLUSION}

The study was focused on the participatory demonstration of demand-driven bread wheat technologies diffusion high land of Wollo eastern Amhara region, Ethiopia. Hibist variety was demonstrated in the comparison with local variety in Jama and Meket district. The collected experimental data were analyzed by using ANOVA, pair wise ranking matrix and partial budget analysis. The result and discussion show yield and yield related parameters statistically significant among treatments. Field day was organized two times and farmers visit the demonstration plots and select the best varieties based on their own listed criteria. Based on farmers' preference analysis Hibist variety with improved management, local 
variety with improved management and local variety with farmers practices ranks first, second and third at Jama district while second, first and third at Meket district respectively. Moreover, the result of partial budget analysis showed that the improved variety and local variety with recommended production package were highly profitable than local variety with farmers' practices. The sensitivity analysis also proved that producing Hibist variety with improved management is economically feasible even though there exists price shock compared with local variety with farmer practices. Finally, spearman's correlation coefficient indicates that farmers' preference evaluation and the actual measurement are coincided. Therefore, improved bread wheat variety Hibist with recommended production package should be popularized for mass end users through scale up extension approach.

\section{ACKNOWLEDGMENT}

The authors would like to extend cordial thanks to Agricultural Growth Program II (AGP-II) for its financial support. We also thanks Amhara Agricultural Research Institute (ARARI) and Sirinka Agricultural Research Center (SARC) for supplying necessary resource and allowing for implementation of this activity in 2019/2020. Besides, authors are grateful to host farmers, experts and development Agents who made their own contribution throughout the implementation process.

\section{REFERENCES}

Alelign, K. and Regassa, E., 1992. Bahir Dar Mixed Farming Zone: Diagnostic Survey Report. Research Report No .18. IAR, Addis Ababa.

Amare, A., 2015. Review on vertisol management for the improvement of crop productivity in Ethiopia. Journal of Biology, Agriculture and Healthcare, 5(12), pp.92-103.
Bekele, H., Verkuijl, H., Mwangi, W. and Tanner, D., 2000. Adaptation of improved technologies in Adaba and Dodola Weredas of the Bale highland Ethiopia. International Maize and Wheat Improvement Centre (CIMMYT) and Ethiopian Agricultural Research Organization (EARO)Addis Ababa Ethiopia.

Bezabeh, E., Haregewoin, T., Hailegiorgis, D., Daniel, F. and Belay, B., 2015. Change and growth rate analysis in area, yield and production of wheat in Ethiopia. Journal of Agriculture and Environmental Management, 4(4), pp.189-191.

Chimdo, A., 2008. A practical Guide to Farmers Research Groups, Ministry of Agricultural and Rural Development and Rural Capacity Building Project (RCBP), Ethiopia

CIMMYT Economics Program, International Maize and Wheat Improvement Center, 1988. From agronomic data to farmer recommendations: an economics training manual (No. 27). CIMMYT.

CIMMYT (International Maize and Wheat Improvement Center), 2014. Wheat production and Use: Ethiopia. http://wheatatlas.org/country/production /ETH/0.

CSA (Central Statistical Agency), 2015. Report on Area and Production of Crops (Private Peasant Holdings, Meher Season) The Federal Democratic Republic of Ethiopia Central Statistical Agency Agricultural Sample Survey Volume I, 2014 / 2015 (2007 E.C.) (March, 2015).Addis Ababa, Ethiopia.

CSA (Central Statistical Agency), 2016/17. Report on Area and Production of Major Crops. Statistical Bulletin 584. Addis Ababa, Ethiopia

Ferdous, Z., Datta, A., Anal, A.K., Anwar, M. and Khan, A.M.R., 2016. Development of home garden model for year round 
production and consumption for improving resource-poor household food security in Bangladesh. NJASWageningen Journal of Life Sciences, 78, pp.103-110.

Gorfu, D. and Hiskias, Y., 2000. Yield loss of crops due to diseases in Ethiopia. Pest Management Journal of Ethiopia, 5, pp.55-67.

Hussein, A.M.S., Helmy, I.M.F., Mustafa, B.E., 2006. Effect of barley flour and some of their functional ingredients on quality of pan bread. Minufiya Journal of Agricultural Research, 31, 877-897.

Mulatu, K., 2015. Effect of Mineral NP and Organic Fertilizers on the Productivity and Nitrogen Use Efficiency of Bread Wheat (Triticum aestivum L.) in Gozamin District, North Western Ethiopia. PhD Dissertation, Haramaya University, Haramaya.

Omer, G.M., 2015. Bread wheat production in small scale irrigation Economics and Extension ISSN:2329-9797 Vol.395), pp.144-150, May, 2015.

Russell, T., 1997. Pair wise ranking made easy. In: PLA notes No 28, Methodological complimentary. International Institute of Environmental and Development (IIED), London, pp. 25-27.

Steel, R.G. and Torrie, J.H., 1980. Principles and Procedures of Statistics McGrawHill Book Co. Inc., New York, 481.

Teame, G., Seid, E. and Diriba, L., 2017. Participatory Evaluations of Faba Bean (Vicia Faba L.) Varieties in Enda Mekoni District, Northern Ethiopia. African Journal of Agriculture, 4(2), pp. 263-68.

Teklu, T., 2001. Emerging Informal Land Markets: A Quest for Equitable and Efficient Land Tenure Systems.

Tafere, M., Dessalegn, T. and Dessalegn, Y., 2012. Participatory Varietal Selection of Faba Bean (Vicia Faba L.) for Yield and
Yield Components in Dabat District. Wudpecker journal of agricultural research, 1(7), pp.270-74.

Tolesa, A., 2014. Adoption of improved agricultural practices and wheat production efficiency of smallholders in Arsi zone of Ethiopia. Ph.D. Dissertation. Haramaya University, Ethiopia.

Warner, J., Stehulak, T. and Leulsegged, K., 2015. Woreda-Level Crop Production Rankings in Ethiopia: A Pooled Data Approach. International Food Policy Research Institute (IFPRI). Addis Ababa, Ethiopia.

Wondimu, B., 2016. Participatory Variety Selection of Faba Bean for Yield Components and Yield at Highlands of West Hararghe, Eastern Ethiopia. International Journal of Plant Breeding and Crop Science, 3(1), pp.99-102. 